\title{
25 The common response to COVID-19
}

\author{
The EU on the road toward \\ de-crisisification?
}

Cristina Ares Castro-Conde

\subsection{Introduction}

The European Union (EU) is a unique federal arrangement. Since its establishment as a fully fledged political system by the Treaty of Maastricht in the early 1990s, it combines functional, intergovernmental, and federal features. These features vary and fluctuate across policy areas and over time. The shifting mixture of rationales for the EU - problem-solving and political - has characterized the entire process of European integration since its very inception as the European Coal and Steel Community in 1951. In the EU, political interests are based on a combination of national interests and the EU general interest.

Within the European Union, the distribution of powers is between the Member States and the supranational bodies of the EU. These supranational bodies are limited by two factors.

Firstly, EU institutions can only execute those competences explicitly transferred to them by the Member States in "the Treaties".

There are three main types of EU competences:

1 Exclusive competences: trade, competition in the single market, and monetary issues for the euro area member countries, among others.

2 Shared competences: areas shared with the Member States - the most frequent type; as the economic union beyond monetary policy, economic, social, and territorial cohesion, and research.

3 Supporting competences: areas where the federal government supports Member States financially or administratively, i.e., health, education, and tourism.

Secondly, the principle of subsidiarity must be respected regarding powers that are not the exclusive competence of the EU. Subsidiarity in federalism means that decisions should be handled by the least centralized competent authority. The EU handles these matters under Article 5(3) of the Treaty of the European Union (TEU) and Protocol (No. 2).

Article 5(3) shows this clearly:

under the principle of subsidiarity, in areas which do not fall within its exclusive competence, the Union shall act only if and in so far as the objectives of the proposed action cannot be sufficiently achieved by the Member States, either at central level or at regional and local level, but can rather, by reason of the scale or effects of the proposed action, be better achieved at Union level.

DOI: $10.4324 / 9781003251217-25$ 
However, the EU fiscal capacity has been extraordinarily limited. Before the COVID-19 pandemic, the EU budget has represented 1 percent of the Gross National Income of all the EU Member States. Instead of constituting a tool to stimulate the economy, the common budget has been an instrument to back national public investments in infrastructures and knowledge that aims to foster a smarter allocation of national resources and better planning in most EU countries. The result has been that the application of the idea of solidarity, not just between richer and poorer social groups, but also between more and less capable Member States has been unworkable.

Yet fiscal solidarity will continue to be in need when the strategy of recovery will reach the end. Moreover,

even in this emergency, with the creation of the Next Generation EU, the European budget has been temporarily expanded to only a little less than 2 percent of the EU GDP. In the US, by contrast, the federal budget is 21 percent of the US GDP.

(Stiglitz 2020, p. 19)

Despite all this, EU bodies, above all the European Commission, have been affected by two factors: the "centralization of power induced by von der Leyen's strong

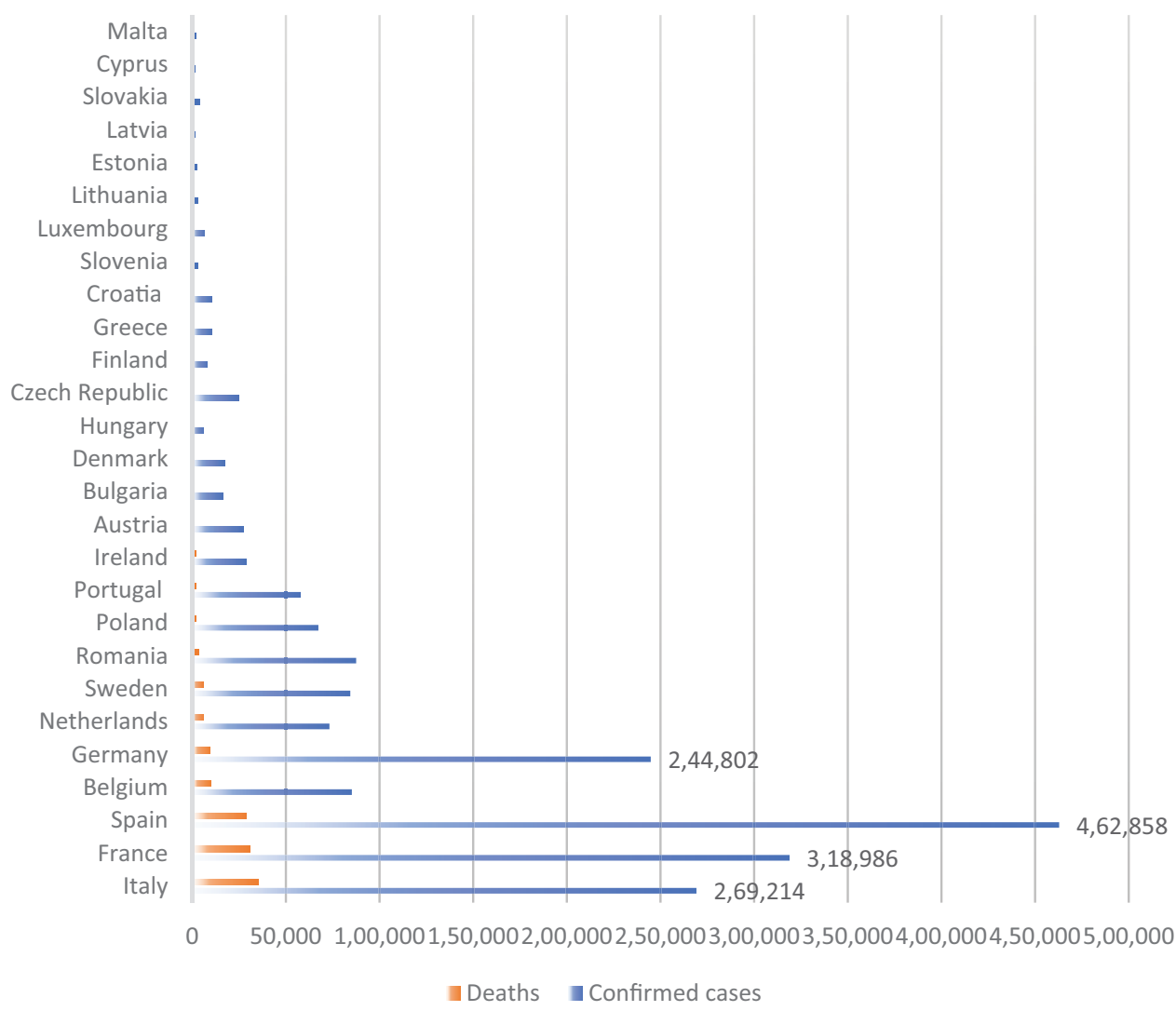

Figure 25.1 Confirmed Cases and Deaths Due to COVID-19 in the European Union*. "EU27 confirmed cases: 1.924.458; EU27 deaths: 140.053 (On September 1, 2020).

Source: Author's own work with data issued by the Johns Hopkins University (Coronavirus Resource Center). 


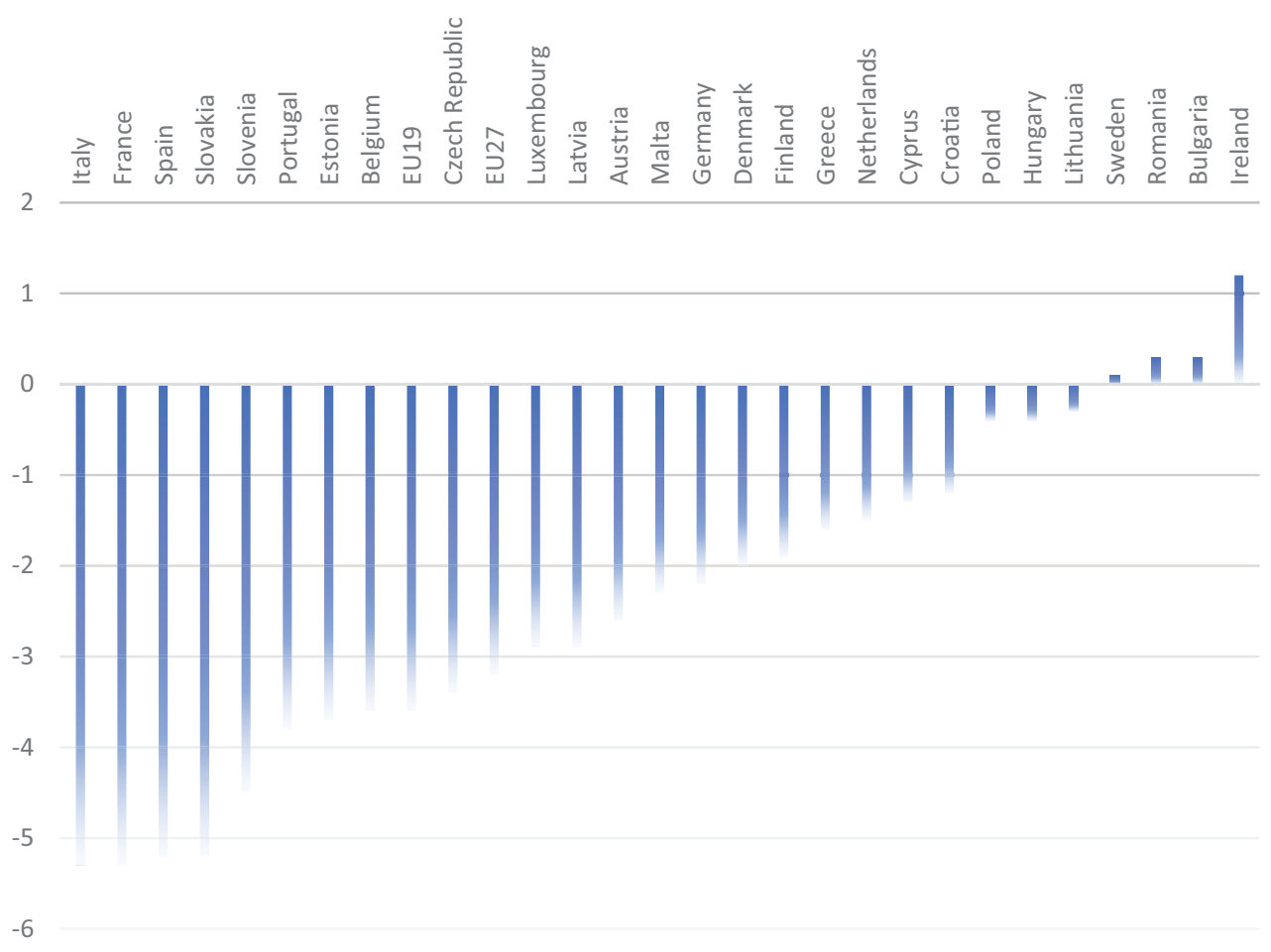

Figure 25.2 Economic Costs of COVID-19 in the European Union*.

* GDP growth in the first quarter of 2020: EU27, -3.2; EU19 (euro area member countries), -3.6.

Source: Author's own work with data issued by Eurostat.

presidential approach to crisis management" (Russack and Fenner 2020, p. 11) and the powers of the European Central Bank. Because of these factors, the EU has achieved success in responding to the COVID-19 pandemic, the main human and economic costs of which in the EU federal system are summarized in Figures 25.1 and 25.2. The reaction has demonstrated the capacity of the supranational institutions to learn from their own mistakes made during the "polycrises" of the 2010s, and it might point to a steady de-crisisification of EU policymaking. ${ }^{2}$

Moreover, it is worth highlighting that in response to the COVID-19 pandemic, "unlike during the economic and financial crisis, the community method was not replaced by intergovernmental action. Where formal decision-making was applied, the regular decision-making channels were used. Instead of circumventing, processes were accelerated" (Russak and Fenner 2020, p. 2).

Besides, due to their significance, this analysis emphasizes some EU pitfalls for crisis management, in comparison with other federal systems. This examination goes beyond the scope of the crisis coordination arrangements initiated by the Dutch Presidency of the Council in 2005. The Dutch Presidency included procedures for abbreviated decision-making, a crisis support team of experts, and financial resources for risk prevention (Rhinard 2019, pp. 619-620).

The "multilevel politics trap" (Zeitlin, Nicoli and Laffan 2019) must be mentioned. Mainstream country leaders still today tend to avoid uncertainty in bargaining on 
Table 25.1 Key Statistics on COVID-19 in the European Union as of 10 January 2021

\begin{tabular}{lllll}
\hline $\begin{array}{l}\text { Cumulative } \\
\text { Cases }\end{array}$ & $\begin{array}{l}\text { Cumulative Cases per } \\
\text { 100,000 Population }\end{array}$ & $\begin{array}{l}\text { Cumulative } \\
\text { Deaths }\end{array}$ & $\begin{array}{l}\text { Cumulative Deaths per } \\
100,000 \text { Population }\end{array}$ & $\begin{array}{l}\text { Case Fatality } \\
\text { Percentage }\end{array}$ \\
\hline $17,292,252$ & $3,892.5$ & 373,777 & 84.1 & 2.2
\end{tabular}

Source: European Economic Forecast, Autumn 2020. Retrieved from: https://ec.europa.eu/info/sites/ default/files/economy-finance/ip136_en_2.pdf

the supranational level to avoid national contestation from their Eurosceptic rivals. This adds a complicating factor into the "prisoner's dilemma" game that mainstream country leaders are forced into playing. Consequently, crucial policy decisions on sensitive areas or Treaty reform are postponed.

The gap that might emerge between the expectations of EU citizens and the delivery capacity of the supranational institutions at times of crisis may cause dissatisfaction with EU membership in several countries. There is also the fact of occasionally growing support for Eurosceptic parties and discourses to deal with as well. This is related to the fact that, in the EU, democratic legitimacy continues to rest to a great extent on a performance criterion. This is sometimes called "output legitimacy" or the ability to govern effectively. These days there is still a danger of country leaders ignoring "input legitimacy" which is "focused on citizens' attitudes toward and engagement in a political community along with the responsiveness of governments to citizens' political demands and concerns" (Schmidt 2015, p. 16) (Table 25.1).

\subsection{Some enduring EU pitfalls for crisis management}

In moving forward, the EU remains particularly unsuited to crisis management, for the following four reasons:

1 EU bodies can only act within competences transferred to them by the Member States.

2 EU bodies' policy solutions must fit within the EU budget.

3 EU bodies share power and have overlapping executive attributes with Member States.

4 There are many sources of EU leadership both supranational and national.

The EU is the sole organization of regional integration with autonomous supranational institutions. Regarding the legislative branch, the European Parliament - the only EU body whose members are directly elected (since 1979) - is like a house of representatives or house of commons, and the Council of the EU represents the Member States through their governments and is similar to a Senate. The European Parliament has been enormously empowered over time, especially by the last reform of "the Treaties" or the Lisbon Treaty (2009). However, the European Parliament continues to be weaker than the Council of the EU, on fiscal issues, among other relevant themes.

The Treaty of Lisbon put both chambers on an equal footing in terms of the annual budget of the EU. However, everything the EU undertakes must fit the multiannual financial framework (MFF) or the EU mid-term budgetary planning. The Lisbon Treaty did grant the European Parliament a veto right over the MFF, under a special 
legislative procedure called "consent." The same rationale, but under a more favorable formula for the Council, is applicable to reforming the EU budget revenues (the socalled "own resources system"), for which the procedure is also a special one referred to as "consultation." Hence, regarding EU revenues, the European Parliament holds a limited right to delay eventual changes prior to the Council's say. Indeed, for both the MFF and the own resources system, national governments have preserved their individual veto rights because all EU Council decisions must be unanimous.

Today, the basic structure of the EU legislative branch is straightforward, with an increasing balance between its two chambers, the European Parliament, and the Council of the EU. A third major EU body, the European Commission performs certain legislative functions as well, in terms of "delegated acts" at the implementation stage, under comitology (the scrutiny of its committees). However, this only works when the Commission has previously been granted these implementing powers in the text of a law passed by the legislators and is always subject to limits and the scrutiny of both chambers. ${ }^{3}$

Also, there is a fourth EU body that shares executive powers, the European Central Bank. That means the EU federal system divides its executive powers among the following bodies:

1 European Council (consisting of the 27 leaders of the Member States)

2 European Commission

3 European Central Bank

4 Council of the European Union (the second house of the European Union: It must approve legislation and consists of government ministers of each of the $27 \mathrm{Mem}-$ ber States)

In addition, there is a consensus-based style of decision-making that characterizes the whole supranational setting. Such a complex system limits the visibility of "the opposition" on the EU level and poses a challenge for citizen control.

The EU has not suffered from a lack of leadership over time. But there are too many doors that can be opened, and behind each, you will find a potential leader. There

Table 25.2 Some Pitfalls of the European Union in Crisis Management

- The nature of EU competences: Supranational institutions cannot take actions beyond those competences transferred to them by the Member States in the Treaties, and the principle of subsidiarity has been applied strictly.

- The reduced common fiscal capacity: Until now, the total amount of own resources allocated to the Union could not exceed 1.20 percent of the sum of all the Member States' Gross National Income (GNI). The latest increase of the own resources ceiling to 2.00 percent of GNI is temporary. It will be decreased to 1.40 percent of GNI when the recovery fund for Europe comes to an end. Moreover, EU Member States have retained their individual veto rights over EU revenues.

- Power-sharing on the EU level: The European Commission, the European Central Bank, the EU Council, and the European Council share EU executive attributes with partial overlaps.

- Numerous (hypothetical) sources of leadership: Leaders include all presidents of the EU institutions, the German Chancellor, the French President, different groups of Member States, the leaders of the political groups in the European Parliament, among others. 
are different presidents of EU bodies who have power in this system. These are the presidents of the European Commission, the European Central Bank, the European Council, the Council of the European Union (rotating among the Member States once every six months), among others. There are also the national leaders of France and Germany, as the EU's frontrunner Member States (Table 25.2).

\subsection{What has been new in the EU response to the COVID-19 pandemic?}

Compared to the past ten years of improvisations (Van Middelaar 2019), along with some other federal systems in spring 2020, the EU reacted quickly. The EU massively delivered as much support as possible for citizens and member countries.

There are three major differences in the EU response to the COVID-19 pandemic in comparison to its management of the Great Recession:

1 the speed of EU decision-making.

2 the separation of Germany from the group of Member States that is called "frugal four" (Austria, Denmark, the Netherlands, Sweden).

3 the return of the "ever closer union" formula in the EU-27 following the Brexit, as one of the options on the table at disposal to make progress (Table 25.3).

Moreover, in response to the COVID-19 pandemic, the institutions that make up the EU executive and legislative branches acted in a more harmonized manner than usual. In fact, the measures approved were connected to the working plan and the priorities for the current institutional cycle 2019-2024 that had been negotiated after the 2019 European election by the Commission, the European Parliament, and the European Council.

The genuine "game changer was the Franco-German proposal to distribute grants of $€ 500$ billion to Member States in need" (Ladi and Tsarouhas 2020, p. 1049). A few days after this proposal, the Commission presented the Recovery plan 'Next Generation EU' with a budget of $€ 750$ billion. The sequence of the intergovernmental and the supranational pushes was crucial. Certainly,

the Franco-German proposal, followed by the Commission proposal, represents an instance of activism by policy entrepreneurs who sought to use the window of opportunity offered by the crisis. In doing so, they engaged in double loop learning, introducing a new organizational and normative dimension to economic governance.

(Ladi and Tsarouhas 2020, p. 1051)

The EU behaved differently than it did during the former Euro area crisis. The FrancoGerman tandem bargained together from an early moment this time.

They did so partly because the German Chancellor Angela Merkel rapidly understood two things:

1 The concerns of her own automotive sector that "clamored for an Italian rescue to shore up their supply chains in Northern Italy as much as their sales across Europe” (Schmidt 2020, p. 1148). 
Table 25.3 Core Economic Responses of the European Union to the COVID-19 Pandemic

\section{EU budget}

- Immediate amendments to the EU 2020 budget: €3.1 billion for medical supplies, testing kits, field hospitals, patient transfers for treatment in other Member States and repatriation of EU citizens; further amendments have been proposed by the European Commission (an additional $€ 11.5$ billion in 2020 to EU countries for repair and recovery).

- Rapid redirection of cohesion funds:

- Coronavirus Response Investment Initiative, to support healthcare systems, mediumsized enterprises (SMEs) and labor markets, €37 billion.

- Up to $€ 28$ billion of the 2014-2020 MFF not yet allocated to projects made available for the crisis response.

- Up to $€ 800$ million from the EU Solidarity Fund for the hardest-hit Member States, by extending the scope of this instrument to public health crises.

- Coronavirus Response Investment Initiative Plus (additional flexibility in the use of structural funds).

- Three safety nets (€540 billion):

- For workers: temporary support to mitigate unemployment risks in an emergency (SURE) - loans to Member States of up to $€ 100$ billion.

- For businesses: $€ 200$ billion for a pan-European guarantee fund put in place by the European Investment Bank - loans for companies with a focus on small and mediumsized enterprises.

- For Member States: Pandemic Crisis Support set up by the European Stability Mechanism - loans to euro area countries up to 2 percent of their GDP and a total of $€ 240$ billion.

- Multiannual financial framework (MFF) for the years 2021-2027 and the EU's coronavirus recovery plan:

- EU MFF 2021-2027 (€1,074.3 billion)

- Recovery plan “Next Generation EU” (€750 billion)

\section{Monetary policy}

Pandemic emergency purchase program launched by the European Central Bank, €1,850 billion.

\section{Competition policy and Economic union beyond monetary policy}

Maximum flexibility in the application of EU rules on state aid measures and in general national public finances and fiscal policies to accommodate exceptional spending in order to support companies and citizens.

Source: Official data issued by the Council

2 The economic effects of the pandemic in Southern Europe could put at risk the stability of the Eurozone. Consequently, it was possible for France to break certain enduring German taboos, such as, allowing the European Commission to raise more financial resources on the markets as well as hugely extending EU common spending and grants.

Another element that facilitated the separation of Germany from the "frugal four" was the German Presidency of the Council from 1 July to 31 December 2020. This institutional position, which was conducted under the motto "Together for Europe's recovery," urged Germany to play the bridge-builder or honest broker role as well as to take more responsibility for the fate of the entire Union. Ultimately, Angela Merkel 
wanted to close her period as Chancellor prior to the 2021 German general election in the most determined way. And many would repeat the phrase "who but Angela Merkel's Germany, the EU's biggest economic power, could steer the EU through these rough seas?" (Koenig and Nguyen 2020, p. 1).

However, the ocean had too many sidewinds. Although all Member States wanted to compromise on two major issues - the still pending of approval MFF 20212017 and the new Recovery plan "Next Generation EU” - they all had different expectations.

In particular, the common negotiation position of the "frugal four" (Austria, Denmark, the Netherlands, Sweden) acted as a destabilizer during weeks due to its harsh opposition to some red lines drawn by other groups of countries. The red-liners included Southern Europe, or the Visegrad Group (Czech Republic, Hungary, Poland, Slovakia). In addition, the "frugal four" put too much emphasis on the digital agenda and new green issues, in detriment of the most traditional EU policies (i.e., the Common Agricultural Policy and cohesion policy). They also pushed for rule of law conditionality for states to receive recovery funds. Furthermore, the "frugal four" plus Finland felt uncomfortable about joint debt and new EU's own resources, and they preferred loans over grants to support recovery.

A clear example of the relevance of the honest broker role played by Germany during its last Presidency of the Council was the deal reached with Hungary and Poland on the rule of law conditionality regulation. Without any change on the agreement, the EU let the European Court of Justice rule on the mechanism before the Commission can use it.

Brexit was the third key novelty. The absence of the UK has diminished in practice the leeway of the "frugal four," and more particularly, Denmark's and Sweden's, countries that are not members of the Euro area. Without a doubt, Brexit has reduced the structural significance of the gap between Member States who are in the Euro area and those who are out.

The idea of flexible integration or country variations in EU membership was historically accepted as the last recourse for two problems:

1 Stubborn policy differences;

2 A means of formalizing relations with European countries outside the EU, such as Norway, Switzerland, or Turkey.

The elephant in the room had been the problem of accommodating British policy demands over time. Once the elephant had departed, things changed. The European Commission in 2017 had opened up the possibility of converting flexible integration into a generally acceptable alternative to the idea of "more Europe" for all EU countries. This suggestion was supported by France.

What is "more Europe"? It is the heart of the European integration process - instead of just the brain - as the Treaties never stopped to recognize. It can be read in the original functional (problem-solving) sense of more integration to complete and maintain the single market in good condition, but also according to the federal agenda. This interpretation means a greater concern about solidarity on the EU level, along with an enhanced role for the European Parliament, regional and local governments, and EU citizens. ${ }^{4}$ 
Besides, the achievement of some new advances toward a more federal Europe seems feasible today not just because of COVID-19 and Brexit but also due to the evolution of public opinion data. This took place after the end of the Great Recession. A more federal Europe emerged after the late maturing of some institutional changes introduced by the Lisbon Treaty - in particular, the empowerment of both the European and national Parliaments. The sum of all these dynamics is good news from a federal perspective when a conference on the future of Europe is about to be launched.

\subsection{What must be improved in the EU to cope with crisis management?}

Today "the decision-making machinery of the EU is multi-layered and has proven to be not only solid and resilient but also equipped to make speedy decisions and to modernize its way of working" (Russack and Fenner 2020, p. 13). However, horizontal coordination on the national level remains an Achilles' heel of the EU political system.

Bringing together EU countries about defining their spheres of power posed serious challenges in the first weeks of the pandemic. In those days,

the EU looked uncoordinated with the disorganized adoption of lockdowns. The absence of exports of medical equipment from EU countries to Italy gave the impression that protectionism dominated the reaction of EU countries. The reintroduction of internal border controls and the suspension of the freedom of movement by 17 member states, with a complete lack of coordination was not a positive sign for European integration either.

(Wolff and Ladi, 2020, p. 1027)

Since the Member States retain the power to decide on health, education, tourism, and other areas that are key during the pandemic, while the EU's role is just a supporting one on these domains, the reputation of the whole EU suffered.

In the health sector,

when Covid-19 hit, the EU had two main governance frameworks through which it could organize its immediate response to the public health crisis. The first was the health security framework set up by the 2013 Decision on Serious Cross Border Threats to Health (herein the Health Threats Decision), which established a set of structures for emergency planning, preparedness, and response. The second was the Civil Protection Mechanism (CPM), which facilitates cooperation between Member States in the event of a disaster. Both performed as intended and expected in the first phase of the crisis but, reflecting the EU's limited health-related powers, their capacity and reach was inevitable insufficient.

(Brooks and Geyer 2020, p. 1058)

In response to this, EU bodies decided to assume more responsibilities. Although transferring powers to them over these matters seemed unfeasible, there was quite a bit of support in most countries to empower EU institutions in relation to health. Some national data, however, indicated reluctance (see Figure 25.3). 


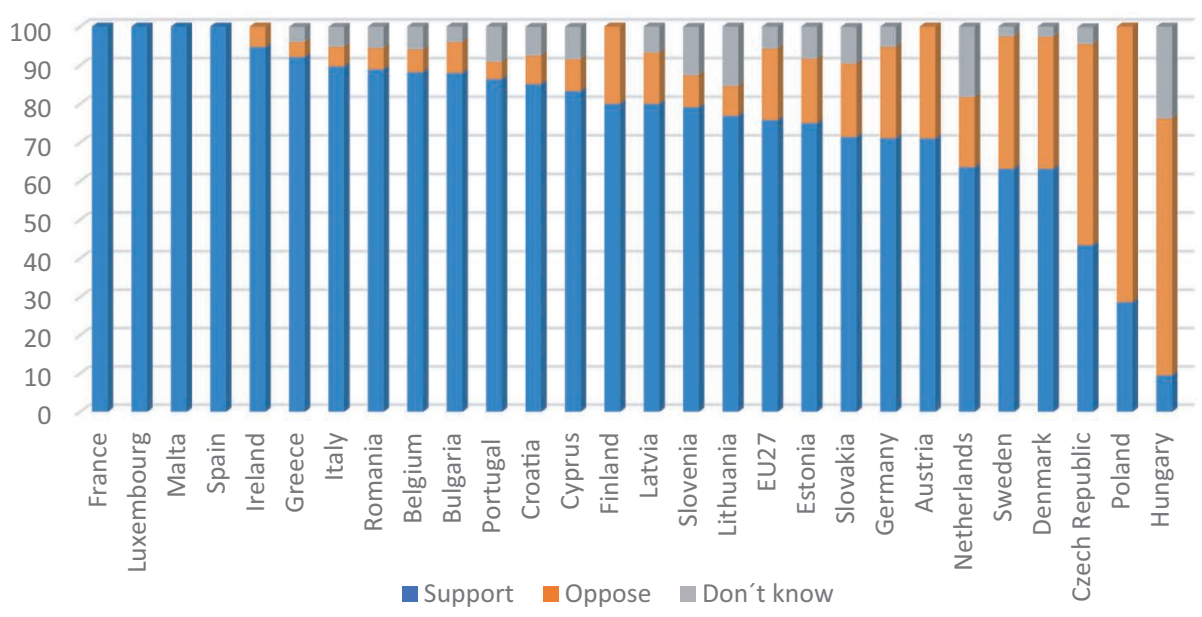

Figure 25.3 EU Member States that Support a Common European Public Health Policy. Source: Author's own work, with data provided by the European Council on Foreign Relations. Available from: https://ecfr.eu/special/eucoalitionexplorer/coronavirus_special/ [Accessed 1 April 2021].

Under the scope of the EU's legal basis for health, internally, the European Commission made the utmost effort to act coordinately. For instance, the European Commission began

by creating the Covid-19 Clearing House for medical equipment within the Secretariat-General. The Clearing House, established by the Commission on the mandate of the European Council, serves to monitor and coordinate developments in Europe's supply chain of personal protective equipment (PPE), medical devices and medicines.

(Russak and Fenner 2020, p. 11)

Furthermore, the Commission demonstrated great ambition with several new initiatives, which included the resourceful EU4Health Programme that will stay on the post-COVID-19 EU health agenda. This initiative will reinforce the European Centre for Disease Prevention and Control and the European Medicines Agency, make medicines accessible, deal with cross-border health threats, and support health systems. The approaching Conference on the Future of Europe will also incorporate a discussion on the future of health.

To gain capacity of response in future health emergencies, the EU bodies must put an end to Member States dependency from third countries concerning goods and services that are essential for the functioning of their public health systems. For a start, common stocks must be generated, and joint supply chains spread. Every effort should be made to strengthen medical research along with cyber security and technology development both on the national and the EU levels.

In addition, regarding communication measures on the EU level, one available solution for preserving the image of the supranational institutions would be better 
Table 25.4 Possible Steps to Cope with Crisis Management in the European Union

- EU institutions should improve coordination among their communication policies. They might delegate a single spokesperson for all press conferences.

- EU bodies must stop competing with one another. In particular, the European Council should constrain itself a bit in favor of the European Commission.

- Parliamentarians and citizens should participate more. Federalism implies more politics and enhanced participation of parliamentarians and citizens. This step goes beyond transparency standards on the EU level.

- The EU must hold more political discussions on policy alternatives. All mainstream Members of the European Parliament should foster political discussions on policy alternatives about the areas affected by the COVID-19 pandemic as well as any other theme on the EU's policy portfolio.

Source: Author's own work

coordination among the communication policies of the different EU bodies. A single EU spokesperson on COVID-19 might be named. This person could systematically be the president of the European Commission.

Likewise, from a federal perspective, the EU must cultivate the democratic standards of supranational decision-making on the input side. The European Parliament should increase the visibility of the policy alternatives that are accessible to respond to the threats posed by the pandemic. This response should be geared to the general interest of the Union instead of national interests. In contrast, the prominence that the European Council acquired regarding the EU response to COVID-19 at least in spring 2020 is problematic from a federal point of view. Policy solutions were mostly framed according to individual Member States' interests, along with intergovernmental alliances. The old-style strategy of self-empowering by the European Parliament did not help much promote the interests of the EU as defined from diverse ideological positions (Table 25.4).

\section{Notes}

1 The expression "the Treaties" refers to the Treaty on the EU (TEU) and the Treaty establishing the European Community, the name of which was changed to the "Treaty on the Functioning of the EU' (TFEU) in December 2009, following the entry into force of the Treaty of Lisbon.

2 The expression "de-crisisification of EU policy-making" is a word game that refers to a well-known article entitled "The Crisisification of Policy-making in the EU" (Rhinard 2019).

3 The term "comitology" refers to the procedures through which the European Commission, with the participation of national representatives, exercises the implementing powers eventually conferred on it by the European Parliament and the Council of the EU, following Article 291 TFUE. This article states that:

(1). Member States shall adopt all measures of national law necessary to implement legally binding Union acts. (2). Where uniform conditions for implementing legally binding Union acts are needed, those acts shall confer implementing powers on the Commission, or, in duly justified specific cases and in the cases provided for in Articles 24 and 26 of the TEU, on the Council. (3). For the purposes of paragraph 2, the European Parliament and the Council, acting by means of regulations in accordance with the ordinary legislative procedure, shall lay down in advance the rules and general principles concerning mechanisms for control by Member States of the Commission"s 
exercise of implementing powers. (4). The word 'implementing' shall be inserted in the title of implementing acts.

4 Article 1 TEU states that "this Treaty marks a new stage in the process of creating an ever-closer union among the peoples of Europe in which decisions are taken as openly as possible and as closely as possible to the citizen."

\section{Bibliography}

Brooks, E. and Geyer, R., 2020. The Development of EU Health Policy and the Covid-19 Pandemic: Trends and Implications. Journal of European Integration, 42 (8), 1057-1076. doi: 10.1080/07036337.2020.1853718.

European Commission, 2017. White Paper on the Future of Europe. Reflections and scenarios for the EU27 by 2025 [COM(2017)2025 of 1 March].

European Commission Website, 2021. EU Budget Own Resources. Available from: https:// ec.europa.eu/info/strategy/eu-budget/long-term-eu-budget/2014-2020/revenue/ownresources_en\#own_res [Accessed 18 February 2021].

European Council on Foreign Relations, 2020. Coronavirus Special. EU Expert Survey on European Cooperation during the Coronavirus Crisis (from 4 to 25 May 2020). Available from: https://www.ecfr.eu/eucoalitionexplorer/coronavirus [Accessed 5 April 2021].

Koenig, N. and Nguyen, T., 2020. Five Takeaways from the German "Corona Presidency." Policy Brief, Jacques Delors Centre/Hertie School, 15 December. Available from: https:// www.delorscentre.eu/en/publications/detail/publication/five-takeaways-from-the-germancorona-presidency [Accessed 5 April 2021].

Ladi, S. and Tsarouhas, D., 2020. EU Economic Governance and Covid-19: Policy Learning and Window of Opportunity. Journal of European Integration, 42 (8), 1041-1056. doi: 10.1080/07036337.2020.1852231.

Rhinard, M., 2019. The Crisisification of Policy-Making in the European Union. Journal of Common Market Studies, 57 (3): 616-633. doi: 10.1111/jcms.12838.

Russack, S. and Fenner, D., 2020. Crisis Decision-Making. How Covid-19 Has Changed the Working Methods of the EU Institutions. CEPS Policy Insights, Number 17/July.

Schmidt, V.A., 2015. The Eurozone's Crisis of Democratic Legitimacy: Can the EU Rebuild Public Trust and Support for European Economic Integration? European Economy Discussion Papers, Number 15/September. Directorate-General for Economic and Financial Affairs of the European Commission. doi: 10.2765/5015 (online).

Schmidt, V.A., 2020. Theorizing Institutional Change and Governance in European Responses to the Covid-19 Pandemic. Journal of European Integration, 42 (8), 1177-1193. doi: 10.1080/07036337.2020.1853121.

Stiglitz, J.E., 2020. Recovering from the Pandemic: An Appraisal of Lessons Learned. FEPS COVID RESPONSE PAPERS, Number 10/October.

Van Middelaar, L., 2019. Alarums and Excursions: Improvising Politics on the European Stage. Newcastle upon Tyne: Agenda Publishing.

Wolff, S. and Ladi, S., 2020. European Union Responses to the Covid-19 Pandemic: Adaptability in Times of Permanent Emergency. Journal of European Integration, 42 (8), 10251040. doi: 10.1080/07036337.2020.1853120.

Zeitlin, J., Nicoli, F. and Laffan, B., 2019. Introduction: The European Union beyond the Polycrisis? Integration and Politicization in an Age of Shifting Cleavages. Journal of European Public Policy, 26 (7), 963-976. doi: 10.1080/13501763.2019.1619803. 